\title{
THE GILT FOR BREEDING AND FOR MEAT
}

\author{
P.H. BROOKS \\ Seale-Hayne College, Newton Abbot, Devon, U.K.
}

The management of the replacement gilt and her successful integration into the breeding herd continue to present severe problems to both individual producers and the industry as a whole. Every year vast numbers of sows are culled, many before they might have been expected to reach optimum performance, to be replaced by gilts whose performance is generally so indifferent that at best they will only maintain herd performance and at worst may reduce it considerably. This chapter considers the impact of the gilt within the herd and attempts to indicate how some of the worst features of gilt performance may be ameliorated by modifying the management of this capricious animal.

\section{The influence of gilts on herd productivity}

The problem presented by gilts can be summed up as 'too many gilts producing too few piglets with too little predictability'. The high numbers of gilts in herds is a reflection of the culling rate. Recent surveys in Britain, the Netherlands and France estimated culling rates of $34.6 \%, 43 \%$ and $50 \%$ respectively (MLC, 1980a; 1980b; Kroes and Van Male, 1979; Dagorn and Aumaitre, 1979). Culling rate tends to increase as herd size increases (Table 11.1) and as lactation length is reduced (Table 11.2).

Table 11.1 RELATIONSHIP BETWEEN

CULLING OF SOWS AND HERD SIZE

\begin{tabular}{ll}
\hline $\begin{array}{l}\text { Herd size } \\
\text { (sows) }\end{array}$ & $\begin{array}{l}\text { Culled sows } \\
\text { (\%/annum) }\end{array}$ \\
\hline 49 & 29.4 \\
$50-99$ & 33.3 \\
$100-149$ & 36.5 \\
$150-249$ & 38.1 \\
$250+$ & 37.9 \\
Average all herds & 36.9 \\
\hline
\end{tabular}

From Meat and Livestock Commission (1980b)

The increased annual culling rate with earlier weaning does not appear to result from sows having fewer litters but reflects the reduction in time spent lactating. For every sow that is culled a gilt must enter the herd and with culling rates of $30-50 \%$ this means that $15-25 \%$ of all litters are born 
Table 11.2 RELATIONSHIP BETIVEEN CULLING OF SOWS AND AGE AT WEANING

\begin{tabular}{lllll}
\hline $\begin{array}{l}\text { Age at weaning } \\
\text { (days) }\end{array}$ & $\begin{array}{l}\text { Culled sows } \\
\text { (\%/annum) }\end{array}$ & Litters/sow/year & $\begin{array}{l}\text { Average } \\
\text { herd life } \\
\text { (years) }\end{array}$ & $\begin{array}{l}\text { Averageno. } \\
\text { litters/sow }\end{array}$ \\
\hline Below 19 & 42.2 & 2.3 & 2.37 & 5.45 \\
$19-25$ & 36.5 & 2.2 & 2.74 & 6.03 \\
$26-32$ & 39.5 & 2.1 & 2.53 & 5.32 \\
$33-39$ & 35.1 & 2.1 & 2.85 & 5.98 \\
$39+$ & 33.7 & 2.0 & 2.96 & 5.93 \\
Average & 36.9 & 2.2 & 2.71 & 5.96 \\
\hline
\end{tabular}

From Meat and Livcstock Commission (1980b)

Table 11.3. THE INFLUENCE OF PARITY ON TOTAL LITTER SIZE

\begin{tabular}{lccccc}
\hline Litter No. & \multicolumn{3}{c}{ Total liner size } & & \multicolumn{2}{c}{ No. born alive } \\
\cline { 2 - 3 } \cline { 6 - 7 } & $A$ & $B$ & & $A$ & $B$ \\
\hline 1 & 9.9 & 9.7 & 9.3 & 9.2 \\
2 & 10.7 & 10.7 & & 10.2 & 10.2 \\
3 & 11.6 & 11.2 & & 10.8 & 10.6 \\
4 & 11.5 & 11.3 & & 10.6 & 10.8 \\
5 & 12.0 & 11.4 & & 11.1 & 10.7 \\
6 & 11.5 & 11.4 & & 10.3 & 10.8 \\
7 & 11.7 & 11.6 & & 10.6 & 10.8 \\
8 & 11.4 & 11.4 & & 10.4 & 10.7 \\
9 & 11.3 & 11.9 & & 10.2 & 10.9 \\
$10+$ & 12.1 & 12.5 & & 10.2 & 11.0 \\
Unweighted sow mean & 11.5 & 11.5 & & 10.5 & 10.7 \\
Mean \% superiority of sows & 16.2 & 18.6 & & 12.9 & 16.3 \\
\hline A-MLC (1980) & & & &
\end{tabular}

Table 11.4 RELATIONSHIP BETWEEN NUMBER OF LITTERS/CULLED SOW AND REPRODUCTIVE PERFORMANCE

\begin{tabular}{llll}
\hline $\begin{array}{l}\text { Mean litters/ } \\
\text { culled sow }\end{array}$ & $\begin{array}{l}\text { Weaning to } \\
\text { conception interval } \\
\text { (days) }\end{array}$ & $\begin{array}{l}\text { Mean pigs } \\
\text { born/litter }\end{array}$ & $\begin{array}{l}\text { Pigs weaned } \\
\text { sow/year }\end{array}$ \\
\hline$<3$ & 19.9 & 10.17 & 15.5 \\
$3-3.99$ & 18.3 & 10.58 & 16.5 \\
$4-4.99$ & 17.4 & 10.58 & 16.7 \\
$5-5.99$ & 17.4 & 10.69 & 17.1 \\
$\geqslant 6$ & 17.1 & 10.79 & 17.6 \\
\hline
\end{tabular}

From Dagorn and Aumaitre (1979)

to gilts. Unfortunately the litter productivity of the gilt is generally inferior to that of the sow (Table 11.3). Furthermore, the interval to service is generally longer following the first litter than following subsequent litters (Rasbech, 1969). As a consequence of these two factors average herd productivity tends to decline as the culling rate increases (or average herd age decreases). This was clearly demonstrated in the survey of Dagorn and Aumaitre (1979) who found that in herds where the average number of litters produced per culled sow was less than three, annual production was 
Table 11.5 EFFECT OF CULLING RATE ON HERD PRODUCTIVITY

\begin{tabular}{lccc}
\hline & \multicolumn{3}{c}{ Culling rate } \\
\cline { 2 - 4 } & Low & Average & High \\
\hline Culling rate (\%) & 31.3 & 43.4 & 55.4 \\
Litters per sow & 6.56 & 4.55 & 3.42 \\
Litters/sow/year & 2.06 & 1.97 & 1.89 \\
Weaners/sow/year & 17.9 & 17.1 & 16.4 \\
Costweaner & 96.6 & 100.0 & 103.8 \\
(\% of average group) & & 100.0 & 85.2 \\
Labour income/sow & & & \\
(\% of average group) & 114.6 & & \\
\hline
\end{tabular}

(a) Labour income $=$ all income minus all costs excluding labour.

From Kroes and Van Male (1979)

Table 11.6 THE INFLUENCE OF PARITY ON CULLING RATE

\begin{tabular}{llll}
\hline Litter No. & \multicolumn{3}{c}{$\begin{array}{c}\text { Culling rate } \\
(\%)\end{array}$} \\
\cline { 2 - 4 } & Kroes and Van Male (1979) & Dagorn and Aumaitre (1979) & MLC(1980) \\
\hline 1 & 19.6 & 21.2 & 14.4 \\
2 & 16.3 & 15.4 & 14.1 \\
3 & 13.8 & 12.8 & 8.6 \\
4 & 11.6 & 11.2 & 10.9 \\
5 & 9.9 & 10.0 & 8.3 \\
6 & 8.6 & 8.9 & 8.6 \\
7 & 7.0 & 7.4 & 8.3 \\
8 & 5.3 & 5.4 & 9.6 \\
9 & 3.7 & 3.6 & 9.3 \\
$10+$ & 4.2 & 4.1 & 7.8 \\
\hline
\end{tabular}

$15.5 \mathrm{pigs} / \mathrm{sow}$, whereas in herds where culled sows had averaged six or more litters productivity was $17.6 \mathrm{pigs} / \mathrm{sow} / \mathrm{year}$ (Table 11.4). As Kroes and Van Male (1979) have demonstrated, changes in culling rate can have an appreciable influence on both the productivity and profitability of a herd (Table 11.5).

Another feature of gilt performance which should give cause for concern is the high culling rate of gilts following weaning (Table 11.6). In the survey of Dagorn and Aumaitre (1979) the two most important reasons for culling gilts were reproductive failure (38\% of cullings) and lameness $(15 \%)$. Survey data gives little evidence of the extent to which producers discard primiparous animals for poor litter performance. Comments of producers suggest that this practice is still widespread despite evidence showing the low repeatability of litter size (Strang and King, 1970; Eikje, 1974; Bognor et al., 1974). This being the case, there would seem to be very little justification for removing a primiparous female from the herd on the basis of a poor first litter when the size of her second litter has every chance of exceeding that of a gilt introduced as a replacement for her.

\section{Mating age and productivity}

The appropriate age at which to mate a gilt depends upon the criteria we choose to evaluate her performance and her contribution to overall herd 
productivity. Unfortunately inappropriate conclusions are often drawn because of the singlemindedness with which most producers adopt first litter performance as the sole measure of gilt productivity. There is ample evidence in the literature to demonstrate that the number of piglets born in the gilt litter increases with age at farrowing (e.g. Squiers, Dickerson and Mayer, 1952; Omtvedt, Stanislaw and Whatley, 1965; Milojić and Simović, 1968; Strang, 1970; Legault and Dagorn, 1973; Stanković et al., 1973; Beremski and Germanova, 1974; MacPherson, Hovell and Jones, 1977). Unfortunately in all these studies chronological age has been confounded with sexual age (i.e. the number of heat periods experienced) so the relative importance of these two components has been obscured. Nevertheless experiments in which gilts have been subjected to comparable management but mated at different heat periods (and hence different ages) are valuable as they indicate the responses which may be anticipated if producers make conscious decisions to delay mating until later heat periods (Table 11.7).

Table 11.7 EFFECT OF NO. OF HEAT PERIODS AT MATING ON LITTER SIZE OF GILTS

\begin{tabular}{|c|c|c|c|c|}
\hline \multirow[t]{2}{*}{ Author } & \multicolumn{3}{|c|}{ No. of heat periods at mating } & \multirow{2}{*}{$\begin{array}{l}\text { Increase in litter size pe } \\
\text { day delay in mating }\end{array}$} \\
\hline & $l$ & 2 & 3 & \\
\hline $\begin{array}{l}\text { Brooks and Cole (1973) } \\
\text { Pay and Davics (1973) } \\
\text { MacPherson er al. (1977) }\end{array}$ & $\begin{array}{l}8.8 \\
7.9 \\
8.4\end{array}$ & $\overline{9}$ & $\begin{array}{r}9.9 \\
9.3 \\
10.4\end{array}$ & $\begin{array}{l}0.026 \\
0.033 \\
0.062\end{array}$ \\
\hline
\end{tabular}

(a) Assuming two 2 I-day ocst rus cycles

Recently Bichard and Coates (1981, personal communication) studied the relationship between mating age and litter performance in large populations of purebred gilts and derived the following equations:

For Large White gilts, $\quad y=0.16 x+6.38$

For Landrace gilts, $\quad y=0.019 x+5.31$

where $y=$ number born and $x=$ age at effective service.

The increase in litter size for each day's delay in mating implied by these equations (0.016-0.019 piglets) is considerably lower than the rate of increase implied by the data in Table $11.7(0.026-0.062)$.

On the basis of this evidence there can be little doubt that a delay in mating will result in an increase in the size of the first litter. However, it must be questioned whether such an increase represents a real improvement in productivity of the gilt and more importantly whether it will improve overall herd productivity. The results of some theoretical calculations presented in Table 11.8 suggest that the increase in litter size likely to be achieved by delaying mating is insufficient to make up for the time lost by keeping the gilt out of production for an extra 21 or 42 days. Indeed these calculations indicate that to produce a similar output per gilt housed per day, the average performance of gilts mated at the third oestrus would have to be comparable with that found for third litter sows (Table 11.3).

So far the effect of mating age has only been considered in terms of first parity performance. It is also important to consider whether there are any 
Table 11.8 LITTER SIZE NEEDED FOR GILTS MATED AT SECOND AND THIRD HEAT TO MAINTAIN EQUIVALENCE WITH GILTS MATED AT PUBERTY

\begin{tabular}{|c|c|c|c|}
\hline \multirow[t]{2}{*}{ 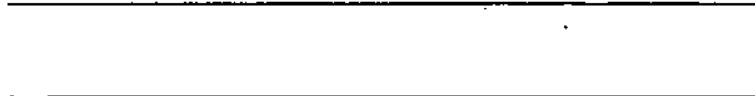 } & \multicolumn{3}{|c|}{ Heat period at mating } \\
\hline & First & Second & Third \\
\hline Mating age (days) & 190 & 211 & 232 \\
\hline $\begin{array}{l}\text { Days from entry to herd to farrowing } \\
\text { (a) } \\
\text { A }\left\{\begin{array}{l}\text { Predicted litter size using Bichard and Coates equation } \\
\text { Litter size required to maintain daily production } \\
\text { equivalent to gilts mated at puberty }\end{array}\right.\end{array}$ & $\begin{array}{r}129 \\
9.4 \\
-\end{array}$ & $\begin{array}{l}150 \\
9.8 \\
11.0\end{array}$ & $\begin{array}{l}171 \\
10.1 \\
12.5\end{array}$ \\
\hline $\mathrm{B}\left\{\begin{array}{l}\text { Litter size after MacPherson et al. (1977) } \\
\text { Litter size required to maintain daily production } \\
\text { equivalent to gilts mated at puberty }\end{array}\right.$ & 8.4 & 9.8 & 10.4 \\
\hline
\end{tabular}

(a)Entry to herd assumed to be at 175 days of age; average interval to puberty 15 days.

(b) Equation for Large White gilts (sec p.214).

Table 11.9 THE EFFECT OF MATING AT PUBERTY, SECOND OR THIRD HEAT ON THE PERFORMANCE OF SOWS OVER THREE PARITIES

\begin{tabular}{lrrr}
\hline & \multicolumn{3}{c}{ Heat mated } \\
\cline { 2 - 4 } & \multicolumn{1}{c}{$I$} & \multicolumn{1}{c}{2} & \multicolumn{1}{c}{3} \\
\hline Pigs weaned (1st litter) & 7.8 & 8.3 & 8.6 \\
Pigs weaned (litters 1-3) & 26.5 & 26.4 & 26.9 \\
Total weight weaner produced litters 1-3 $(\mathrm{kg})$ & 280.7 & 282.4 & 284.8 \\
Weight at mating (kg) & & & \\
Parity 1 & 88.1 & 98.2 & 115.1 \\
Parity 4 & 165.5 & 168.9 & 165.8 \\
\hline
\end{tabular}

From MacPherson. Hovell and Jones (1977)

Table 11.10 EFFECT OF MATING AGE ON THE PERFORMANCE OF SOWS OVER FIVE PARITIES

\begin{tabular}{lcc}
\hline & Early mated & Conventionally mated \\
\hline Mean age at mating (days) & 198 & 237 \\
Pigs born (1st litter) & 8.6 & 9.5 \\
Pigs born (litters 1-5) & 53.7 & 53.8 \\
Pigs born alive (litters $1-5)$ & 51.6 & 50.4 \\
Pigs weaned & 42.6 & 43.8 \\
Mean piglet birth weight $(\mathrm{kg})$ & 1.20 & 1.13 \\
Mean piglet weaning weight $(\mathrm{kg})$ & 9.16 & 9.13 \\
Sow food $/ \mathrm{kg}$ weaner $(\mathrm{kg})$ & 6.1 & 6.5 \\
\hline
\end{tabular}

From Brooks and Smith (1977)

long-term effects of mating at different ages. Although MacPherson, Hovell and Jones (1977) found considerable differences in first litter performance for gilts mated at different heat periods their performance over three litters was almost identical (Table 11.9).

Brooks and Smith (1977) induced puberty at different ages by the use of boar stimuli then mated gilts at their second heat period. Gilts mated at an average age of 198 days produced smaller first litters than gilts mated at 237 days but over five litters the number of piglets born differed by only $0.2 \%$ (Table 11.10). However, the gilts mated at a younger age consumed $6.2 \%$ less food $/ \mathrm{kg}$ weaner produced. These data are consistent with the survey data of Legault and Dagorn (1973) who found that neither the number of 
litters produced nor the herd life of the sow were affected by age at first farrowing and that for each day that mating age was increased, annual sow productivity was reduced by $0.02-0.03$ pigs. They also noted a slight increase in farrowing interval as mating age increased.

It must be concluded from these results that little is to be gained by delaying mating once the gilt has reached puberty. However in practice it may be prudent to delay mating of certain gilts in order to maintain continuity of throughput in the unit. In such cases the 'gilt pool' approach suggested by Brooks (1978) has much to conmend it.

\section{Nutrition of the breeding gilt}

Over the last decade both the management of the gilt and her genetic constitution has changed appreciably. The combined effects of genetic change and earlier mating mean that gilts now start their breeding lives at lighter weights and with smaller fat deposits than they did a decade ago. It is important to consider whether this should influence the nutritional management of the animal. At present there seems to be little reason to -revise recommendations for the nutrition of the gilt around the time of mating and in early pregnancy. The relationships between nutrition and reproduction probably do not differ significantly from those outlined by Anderson and Melampy (1972), Brooks and Cooper (1972) and Brooks and Cole (1974). However there would appear to be a need to review the nutrition of the gilt during the growing period and throughout her reproductive life.

One of the consequences of mating gilts at younger ages is that they generally weigh less. Initially it was thought that this might inhibit their growth and reduce their ultimate liveweight. Such fears (or hopes) have been shown to be groundless. MacPherson, Hovell and Jones (1977) found that initial differences in liveweight had disappeared by the end of the third parity (Table 11.9) and Brooks and Smith (1980) found that early mated gilts caught up with initially heavier control gilts by the middle of the second pregnancy. (Figure 11.1) and had a similar pattern of weight change thereafter. Of rather more significance may be the nature of gains and losses in modern gilts. Current feeding recommendations are based on nutritional studies conducted mainly in the late sixties and have as their underlying premise the depletion of fat reserves during the first two or three parities. Whittemore, Franklin and Pearce (1980) have rightly pointed out that such regimes may not be appropriate to modern gilts starting their breeding life with limited fat reserves. In their studies of gilts on the MLC Commercial Product Evaluation Scheme, they found that although gilts made a net liveweight gain of $22 \mathrm{~kg}$ over their first five parities they actually lost $7.4 \mathrm{~mm}$ of backfat (which they estimated to be equivalent to $8 \mathrm{~kg}$ fatty tissue), so that at the end of the second parity they contained only $5-12 \mathrm{~kg}$ of body fat. Clearly if fat losses of a similar magnitude occurred in succeeding parities most of the sows would have dissipated all their fat reserves by the end of their fourth parity.

There are two ways in which this problem could be overcome; either the fat reserves of the gilt should be increased prior to first farrowing to 

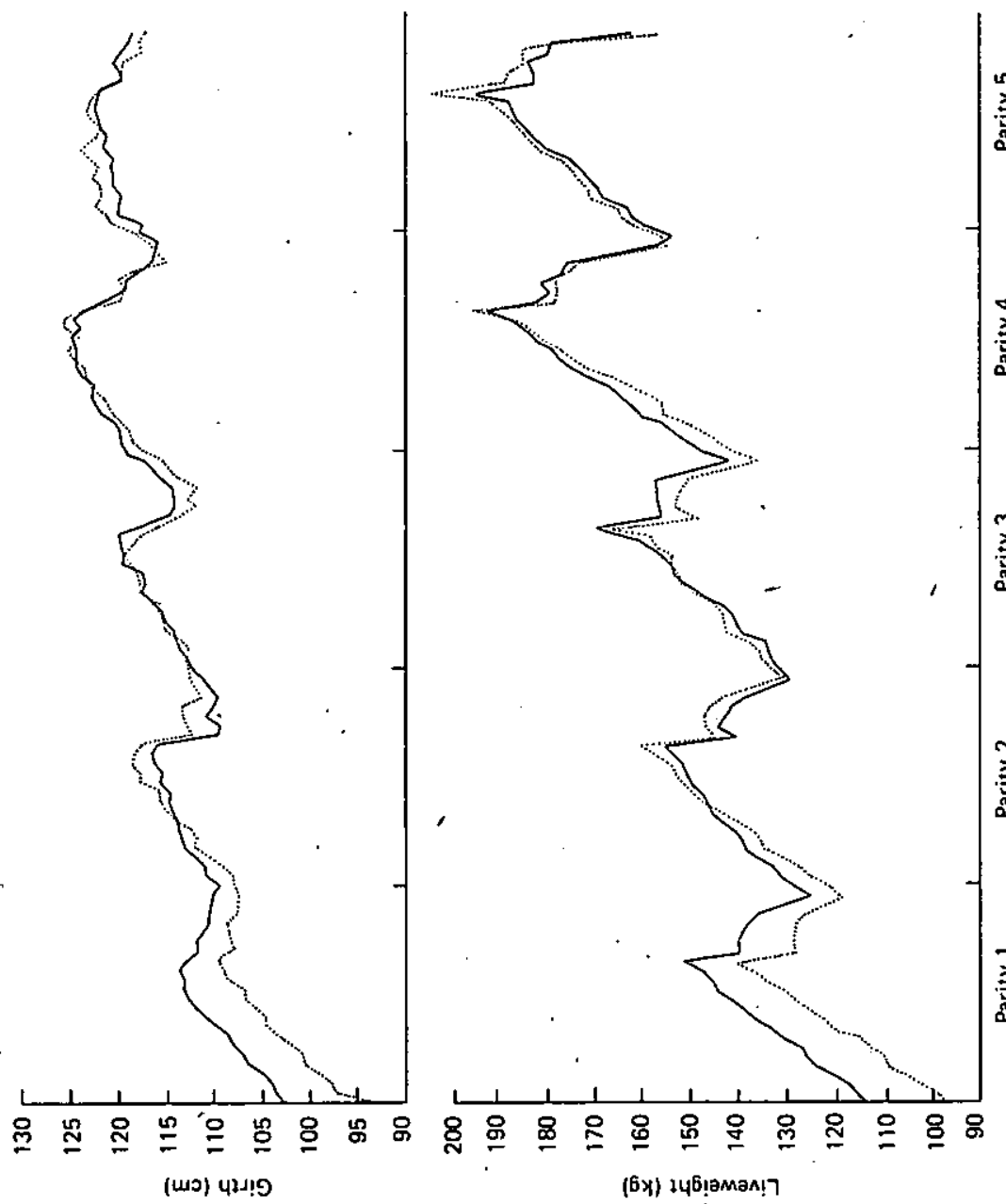

$\vdots$

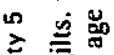

焉

鄚

交岕

象

$\geqslant$ क

递

嘔

증

政

$m$ 击

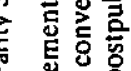
氙 密 …

察焉 늠듬

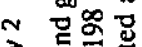

총 . 은 亏 ํㅡㄹ

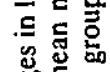

-

는.

焉

额昆 就瓷 
provide fat for later depletion, or the feeding regime of sows should be revised in order to avoid fat depletion. It is doubtful whether increasing fat reserves prior to first farrowing is a practicable solution, for two reasons. First, if the increase in fat intake is to be achieved by a higher feed intake in pregnancy, this is likely to reduce lactation feed intake as it has been clearly demonstrated that increased food intake in pregnancy leads to reduced voluntary feed intake in lactation (Dean and Tribble, 1961; Salmon-Legagneur and Rerat, 1962; Baker et al., 1969). In the experiment of Baker et al. (1969) this resulted in a linear decrease in lactation weight gain with increase in gestation feed consumption (Table 11.11). Even when

Table 11.11 EFFECT OF GESTATION FEED LEVEL ON LACTATION FEED INTAKE AND WEIGHT CHANGE

\begin{tabular}{llcc}
\hline $\begin{array}{l}\text { Daily feed intake } \\
\text { in gestation }\end{array}$ & $\begin{array}{l}\text { Lactation diet } \\
\text { intake } \\
(\mathrm{kg})\end{array}$ & $\begin{array}{l}\text { Gestation } \\
\text { weight gain } \\
(\mathrm{kg})\end{array}$ & $\begin{array}{l}\text { Lactation } \\
\text { weight gain } \\
(\mathrm{kg})\end{array}$ \\
\hline 0.9 & 89.4 & 5.9 & 6.1 \\
1.4 & 90.3 & 30.3 & 0.9 \\
1.9 & 90.5 & 51.2 & -4.4 \\
2.4 & 81.1 & 62.8 & -7.6 \\
3.0 & 71.7 & 74.4 & -8.5 \\
\hline
\end{tabular}

From Baker er al. (1969)

pigs receive the same gestation allowances there is a tendency for gilts which farrow at heavier weights to lose more weight in the following lactation as shown in Figure 11.1 (Brooks and Cole, 1973; Brooks and Smith, 1980). The effect in these two trials was not an effect on appetite as the gilts were fed to scale; nor could it be attributed totally to a higher maintenance requirement in the heavier gilts. In the trial of Brooks and Smith (1980) one result of this phenomenon was that heavier (and fatter) conventionally mated gilts lost more fat during the first lactation and between weaning and remating so that they started their second parity with similar fat deposits to the early mated animals (Table 11.12). It is interesting that although these animals continued to gain weight in subsequent parities (Figure 11.1), fat thickness appeared to stabilize after the second lactation.

From these results it would appear that a more appropriate approach to the problem of maintaining fat reserves may be to prevent their depletion by differential feeding of the sow from first farrowing onwards. Problems are frequently encountered when attempting to rebreed gilts following

Table 11.12 CHANGES IN MIDBACK FAT DEPTH $(\mathrm{mm})^{(\mathrm{a})}$ FOR CONVENTIONAL AND EARLY MATED GILTS

\begin{tabular}{lll}
\hline & Early mated & Conventionally mared $^{(\mathrm{b})}$ \\
\hline Post partum (1st litters) & 18.8 & 25.0 \\
Weaning (1st litter) & 16.8 & 18.2 \\
Remating (2nd parity) & 18.2 & 18.0 \\
3rd parity & 14.6 & 15.3 \\
4th parity & 14.0 & 15.1 \\
\hline
\end{tabular}

From Brooks and Smith, unpublished data (1980)

(u) Minimum fat depth over the spine at the last rib

(b) For details of animals and management see Brooks and Smith (1980) 
weaning. This problem has been considered in earlier papers (Brooks and Cole, 1974; Brooks, 1978). It has been suggested that these difficulties might be induced by the large weight losses which gilts often exhibit during their first lactation and that the problem might be ameliorated by the provision of generous feed allowances after weaning. To the rebreeding problem.has now been added the difficulty that some modern hybrid strains tend to produce smaller litters in their second litters than in their first. A re-examination of the data presented by Whittemore, Franklin and Pearce (1980) demonstrates this point. Of the nine breed groups examined six showed an increase in litter size from first to second litter, one showed no change and two showed a decrease. If the percentage change in litter size is plotted against the change in backfat thickness between weaning and

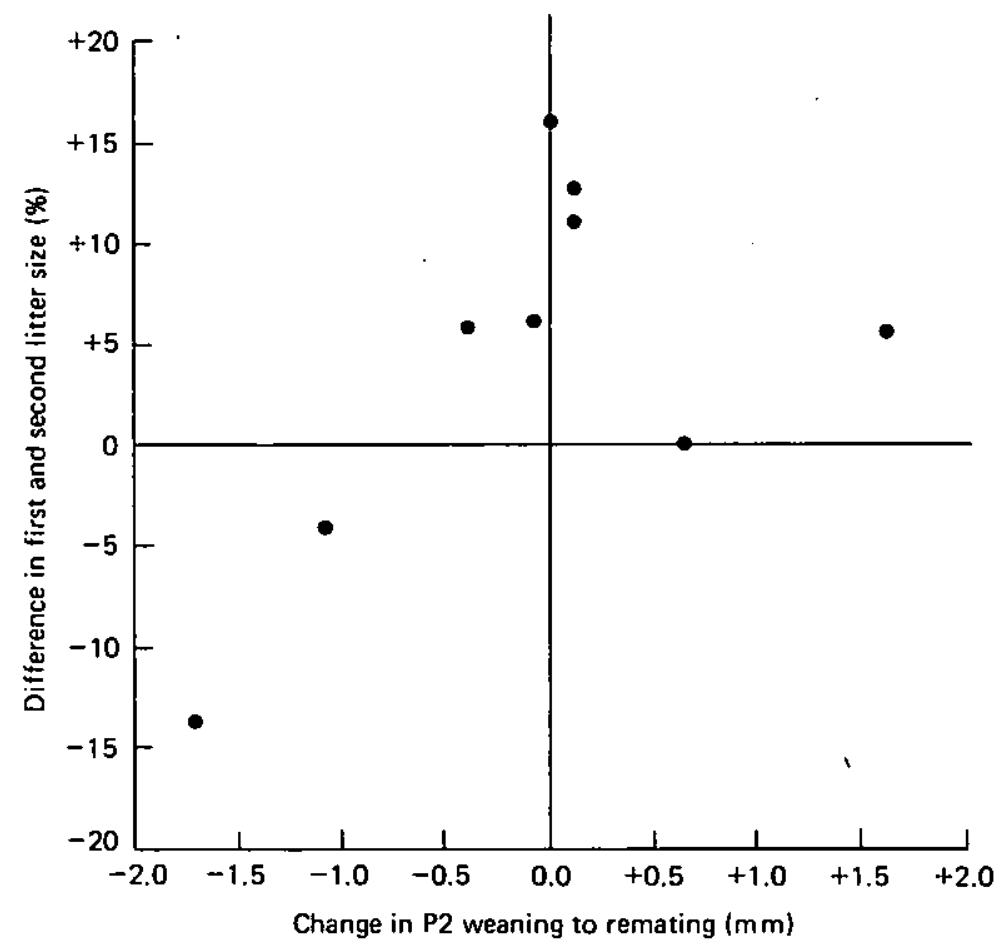

Figure 11.2 Relationship between backfat change and litter size

remating (Figure 11.2), there is an indication that the dynamic changes in body condition may be influencing subsequent litter size. This suggests that some gilts having become catabolic during lactation do not immediately revert to an anabolic state after weaning and as a consequence have reduced ovulation rates. This may well explain the responses to postweaning nutrition reported in earlier papers (Brooks and Cole, 1974; Brooks, 1978). Work in progress at the moment suggests that it is not uncommon for fat depletion to continue after weaning and that on some nutritional regimes repletion may not be apparent until 30-40 days after weaning (Hardy, 1981, personal communication). These dynamic changes 
may well influence ovulation rate at the post-weaning oestrus. Love (1979) has shown that ovulation rate increases from 11.7 at the first post-weaning oestrus to 12.3 at the second. These differences may provide a partial explanation for the increase in litter size with longer weaning to mating intervals reported by Love (1979) and confirmed in our own animals (Brooks, 1980, unpublished data) although by no means all the animals mated $12+$ days after weaning were experiencing their second oestrus (Table 11.13).

Table 11.13 EFFECT OF WEANING TO REMATING INTERVAL ON SUBSEQUENT LITTER SIZE

\begin{tabular}{lcc}
\hline & Mated within /2 days of weaning & Mated 12+ days after weaning \\
\hline Love (1979) & $9.0 \pm 2.5$ & $10.4 \pm 2.1$ \\
Brooks (1980) & $9.34 \pm 2.26$ & $10.54 \pm 1.56$ \\
\hline
\end{tabular}

When taken together all these elements tend to indicate that feed regimes for gilts should pay particular attention to the short term and that problems arising from limited fat reserves should be' solved by the development of more appropriate feeding regimes for gilts from first farrowing onwards.

\section{The gilt as a meat animal (once-bred gilt)}

The possibility of producing a litter of piglets, which could be fattened for slaughter, from gilts that were themselves destined for slaughter has been considered by a number of workers in recent years (Brooks and Cole, 1973; Kotarbinska and Kielanowski, 1973; Pay and Davies, 1973; Brooks, Cole and Jennings, 1975; MacPherson, Hovell and Jones, 1977; Hovell et al., 1977a,b; Brooks and Smith, 1977; Friend et al., 1979). The original impetus for these recent studies was the realization that gilts could be stimulated using the 'boar effect' to achieve puberty at younger ages and lower liveweights (see Chapter 6). It was reasoned that if acceptable litters could be produced from such gilts they might produce a litter and still yield a carcass in the weight range normally associated with heavy manufacturing pigs (77.5-100 kg deadweight). It was further considered possible that pregnancy anabolism might result in the more efficient conversion of food into carcass gains.

Mean litter size of gilts mated at puberty ranged from 7.1-10.5 in the papers listed above, indicating that piglet production from gilts mated at low liveweights is satisfactory. It also proved possible to produce carcasses within the required weight range from a variety of different nutritional and management regimes. It is interesting that in the studies made by Hovell et al. $(1977 \mathrm{a}, \mathrm{b})$ there was no lasting effect of pregnancy on maternal growth. Although there were apparent increases in gain during gestation they did not persist beyond the first nine days after farrowing. Despite this Brooks and Cole (1973), MacPherson, Hovell and Jones (1977) and Hovell et al. $(1977 a, b)$ all found the efficiency of the once-bred gilt to be higher than that of unmated animals when allowance was made for litter production. MacPherson, Hovell and Jones (1977), after allowing for piglet production 
calculated that bred gilts had a food conversion ratio of 2.9:1 compared with 3.6:1 for unmated gilts while Hovell et al. (1977) calculated effective food 'conversion ratios (after allowance' for the litter) ranging from 1.8-3.4:1 for bred gilts compared with 4.7-5.3:1 for unmated animals. Brooks and Cole (1973) used a somewhat different calculation and estimated the food required to produce a weaner pig additional to the requirement for fattening an unmated female to a similar weight. The value was $22.1 \mathrm{~kg} /$ weaner with early weaning and $37.5 \mathrm{~kg} /$ weaner with conventionally weaned pigs, implying a considerable reduction in the food required for piglet production.

Different authors have used different ways of assessing the carcasses from bred gilts. Hovell et al. (1977a) found little difference between the carcass composition of bred gilts slaughtered at nine days post-partum and unmated gilts of the same weight. They also concluded that although there was little difference between the groups in terms of total protein deposited, mated gilts deposited less protein than unmated gilts when corrected to a constant level of fat deposition (Hovell et al., 1977b). Brooks, Cole and Jennings (1975) found that carcasses from bred gilts were significantly less fat than unmated controls and that yield of primal joints was only $0.62 \%$ less. The extent to which trimming of mammary tissue is required varies according to the views of the wholesaler and the interval between weaning and slaughter. Brooks and Smith (1977) found that removal of unregressed or damaged mammary tissue resulted in a loss of $4.9 \%$ of the total weight of the middle.

The value of the carcass depends upon its classification by the purchaser and this in turn is dependent upon the purpose to which the carcass will be put. The results obtained by Brooks and Smith (1977) suggested that the bred gilt is unlikely to be considered as a direct substitute for traditional heavy manufacturing pigs. There are two reasons for this. First the streak block has to be trimmed reducing its yield and altering its shape. In addition the streak block does not produce bacon of acceptable quality, having poor colour and texture. The back block cures satisfactorily but the rashers produced tend to have fat separation and are subject to moisture loss which make them unattractive when packaged. Despite this unsuitability for curing there seem to be few discernible or significant differences in acceptability of cooked fresh meat from bred gilts (Friend et al., 1979).

These results suggest that unless novel manufacturing approaches are developed, for which the once-bred gilt is particularly suited and hence able to command a price premium, the gilt will continue to be classified as a 'sow' for payment purposes.

It appears that in terms of biological efficiency a production system based on once-bred gilts could prove more efficient than conventional systems of production. However, to achieve this improved biological efficiency gilt management has to be of a very high standard. Failure to meet output targets can quickly erode any biological advantage and will have an adverse effect upon the productivity and profitability of the dependent fattening enterprise. Management problems would increase still further on a unit in which all piglets were derived from once-bred gilts as some form of criss-cross breeding system would be needed to maintain the genetic stability of the herd. 
Finally, a question which cannot yet be answered is whether the rapid turnover of breeding stock would reduce herd immunity levels and hence increase health problems. If experience in breeding units is any guide this could be a factor of some significance.

\section{References}

ANDERSON, L.L. and MELAMPY, R.M. (1972). Factors affecting ovulation rate in the pig. In Pig Production, (D.J.A. Cole, Ed.), pp. 329-366. London, Butterworths

BAKER, D.H., BECKER, D.E., NORTON, H.W., SASSE, C.E., JENSEN, A.H. and HARMON, B.G. (1969). Reproductive performance and progeny development in swine as influenced by feed intake during pregnancy. $J$. Nutr. 97 , 489-495

BEREMSKI, S. and GERMANOVA, L. (1974). The optimum age and body weight at first mating and reproductive performance of sows. I. The effect of age. Zhivotnov"dni Nauki 11, 57-63

BOGNOR, H., IVANOUSKI, R., LEDERER, J. and AVERDUNK, G. (1974). Relationship of litter size in successive litters of breeding sows. Zuchthygiene 9,77

BROOKS, P.H. (1978). Early sexual maturity and mating of gilts. $A D A S$ Quart. Rev. 30, 139-152

BROOKS, P.H. (1979). Rearing gilts. Proc. MLC/Farmers Weekly Conf., Cambridge, February 1979

BROOKS, P.H. and COLE, D.J.A. (1973). Meat production from pigs which have farrowed. 1. Reproductive performance and food conversion efficiency. Anim. Prod. 17, 305-315

BROOKS, P.H. and COLE, D.J.A. (1974). The effect of nutrition during the growing period and the oestrous cycle on the reproductive performance of the pig. Livest. Prod. Sci. 1, 7-20

BROOKS, P.H. and COOPER, K.J. (1972). Short term nutrition and litter size. In Pig Production, (D.J.A. Cole, Ed.), pp. 385-398. London, Butterworths

BROOKS, P.H. and SMITH, D.A. (1977). Meat production from pigs which have farrowed. 3. The effect of weaning to slaughter interval on food utilization and carcass quality. Anim. Prod. 25, 247-254

BROOKS, P.H. and SMITH, D.A. (1980). The effect of mating age on the reproductive performance, food utilization and liveweight change of the female pig. Livest. Prod. Sci. 7, 67-78

BROOKS, P.H., COLE, D.J.A. and JENNINGS, W.J.N. (1975). Meat production from gilts which have farrowed. 2. Carcass characteristics. Anim. Prod. 20, 123-131

DAGORN, J. and AUMAITRE, A. (1979). Sow culling: reasons for and effect on productivity. Livest. Prod. Sci. 6, 167-177

DEAN, B.T. and TRIBBLE, L.F. (1961). Reproductive performance of swine fed different planes of energy during gestation. Res. Bull. Mo. agric. Exp. Stn No. 774

EIKJE, E.D. (1974). Phenotypic and genetic parameters of litter size in pigs. Meld. Norg. LandbrHøisk. 53, 23pp.

FRIEND, D.W., LARMOND, E., WOLYNETZ, M.S. and PRICE, K.R. (1979). Piglet 
and pork production from gilts bred at puberty: Chemical composition of the carcass and assessment of meat quality. J. Anim. Sci. 49, 330-341

HOVELL, F.D.DeB., MACPHERSON, R.M., CROFTS, R.M.J. and PENNIE, K. (1977). The effect of energy intake and mating weight on growth, carcass yield and litter size of female pigs. Anim. Prod. 25, 233-245

HOVELL, F.D.DeB., MACPHERSON, R.M., CROFTS, R.M.J. and SMART, R.I. (1977). The effect of pregnancy, energy intake and mating weight on protein deposition and energy retention of female pigs. Anim. Prod. 25, 281-290

KOTARBINSKA, M. and KIELANOWSKI, J. (1973). A note on meat production from pigs slaughtered after first weaning a litter. Anim. Prod. 17, $317-320$

KROES, Y. and VAN MALE, J.P. (1979). Reproductive lifetime of sows in relation to economy of production. Livest. Prod. Sci 6, 179-183

LEGAULT, C. and DAGORN, J. (1973). Incidence de l'âge à la première mise-bas sur la productivité de la truie. Journées Rech. Porcine en France 1973, pp. 227-237. Paris, L'Institut Technique du Porc

LOVE, R.J. (1900). Reproductive performance of first parity sows. Vet. Rec. $104 ; 238-240$

MACPHERSON, R.M., HOVELL, F.D.DeB. and JONES, A.S. (1977). Performance of sows mated at puberty or second or third oestrus and carcass assessment of once-bred gilts. Anim. Prod. 24, 333-342

MEAT AND LIVESTOCK COMMISSION (1980a). Newsletter No. 14, March 1980

MEAT AND LiVESTOCK COMMISSION (1980b). Commercial Pig Production Yearbook 1979

MILOJIC, M. and SIMOVIC, B. (1968). The age of gilts at first farrowing and their fertility. VI Congr. Reprod. A.I., Paris, Resumés, 336

OMTVEDT, I.T., STANISLAW, C.M. and WHATLEY, J.A. (1965). Relationship of gestation length, age and weight at breeding and gestation gain to sow productivity at farrowing. J. Anim. Sci. 24, 531-535

PAY, M.G. and DAVIES, T.E. (1973). Growth, food consumption and litter production of female pigs mated at puberty and at low body weights. Anim. Prod. 17, 85-91

RASBECH, N.O. (1969). A review of causes of reproductive failure in swine. Br. vet. J. 125, 599-616

SALMON-LEGAGNEUR, E. and RERAT, A. (1962). Nutrition of the sow during pregnancy. In Nutrition of Pigs and Poultry, (J.T. Morgan and D. Lewis, Eds.), pp. 207-237. London, Butterworths

SQUIERS, C.D., DICKERSON, G.E. and MAYER, D.T. (1952). Influence of inbreeding age and growth rate of sows on sexual maturity, rate of ovulation, fertilization and embryo survival. Res. Bull. Mo. agric. Exp. Stn No. 494, 40pp.

STANKOVIĆ, M., ZALETEL, I., STANKOUVIC, J. and GROZDANIC, G. (1973). Effect of age at first mating on longevity and lifetime performance of Swedish Large White sows. Arh. poljopr. Nauke Teh. 26, 33-44

STRANG, G.S. (1970). Litter productivity in Large White pigs. 1. The relative importance of some sources of variation. Anim. Prod. 12, 285-333 
224 The gilt for breeding and for meat

STRANG, G.S. and KING, J.W.B. (1970). Litter productivity in Large White pigs. 2. Heritability and repeatability estimates. Anim. Prod. 12, 235243

WHITTEMORE, C.T., FRANKLIN, M.F. and PEARCE, B.S. (1980). Fat changes in breeding sows. Anim. Prod. 31, 183-190 